\title{
Determinant of Repayment Rate of Islamic Mortgate Financing Product
}

\author{
Hawari Muhammad El Baqiy¹, Ferry Ardiansyah²
}

\begin{abstract}
This paper aims to analyze the determinants of repayment rate of mortgage financing in Islamic banking. This research employs logistic regression analytical model; the dependent variables used is rate of collectability while the independent variables are age, number of family member, level of education, bank accounts, balance of savings, track record in Islamic bank $X Y Z$, track record in Central Bank of Indonesia, reference, residential status, length of residence, types of firm, position at workplace, length of work, incomes, length of financing, repayment capacity, appraisal recommendation, size of building, purpose of financing, and finance to value. The result shows that only five determinants are capable of affecting the repayment rate of Islamic mortgage financing or KPR in Islamic bank XYZ in Jakarta, Bogor, Depok, Tangerang, Bekasi, and Cilegon in period of year 2014-2016. Those determinants are both track records in Islamic bank XYZ and Central Bank of Indonesia, types of firm, length of financing, and repayment capacity. At the same time, both track records in Central Bank Indonesia and length of financing have negative effects toward repayment rate of Islamic KPR.
\end{abstract}

Keywords: Islamic Bank, Mortgage Financing, Logistic Regression, Repayment Rate

Abstrak. Penelitian ini bertujuan untuk menganalisis faktor penentu tingkat pembayaran kembali pembiayaan perumahan di perbankan syariah. Penelitian ini menggunakan model analisis regresi logistik; dengan variabel dependen yang digunakan adalah tingkat kolektabilitas sedangkan variabel bebasnya adalah usia, jumlah anggota keluarga, tingkat pendidikan, rekening bank, saldo tabungan, rekam jejak di bank syariah $X Y Z$, rekam jejak di Bank Sentral Indonesia, referensi, status perumahan, lama tinggal, jenis perusahaan, posisi di tempat kerja, lama kerja, pendapatan, lama pembiayaan, kemampuan pembayaran kewajiban, rekomendasi penilaian, ukuran bangunan, tujuan pembiayaan, dan rasio pembiayaan terhadap agunan. Hasilnya menunjukkan bahwa hanya lima determinan yang mampu mempengaruhi tingkat pembayaran pembiayaan KPR syariah atau KPR di bank syariah XYZ di Jakarta, Bogor, Depok, Tangerang, Bekasi, dan Cilegon pada periode tahun 2014-2016. Faktor-faktor penentu tersebut adalah rekam jejak di Bank Syariah XYZ dan Bank Sentral Indonesia, jenis perusahaan, lama pembiayaan, dan kemmampuan pembayaran kewajiban. Pada saat yang sama, rekam jejak di Bank Sentral Indonesia dan lamanya pembiayaan memiliki efek negatif terhadap tingkat pengembalian KPR Islam.

Kata kunci: Bank Syariah, KPR, regresi logistic, tingkat pembayaran kembali

\footnotetext{
1 STEI Tazkia, Indonesia| hawarimuhammad@ymail.com

${ }_{2}^{2}$ Business School, Bogor Agricultural University, Indonesia|ferryard2@gmail.com
} 


\section{Introduction}

Islamic financing for mortgage financing from 2014 to 2016 continues to increase every year. In the 2014 to 2015 period, the growth of Islamic mortgage growth was $9.65 \%$ and in the following year the growth rate of Islamic mortgage financing increased in the previous year by $15.2 \%$, and for growth of NPF alone in 2015 by $3.4 \%$ and on in 2016 the increase of $3.11 \%$ from the previous year.

In Islamic bank $\mathrm{XYZ}$ for its own mortgage financing distribution from 2012 to 2014 continues to increase, but in 2015 the distribution had declined and increased again in 2016. In Islamic bank XYZ itself there are two mortgage financing, which are regular Islamic and mortgage (KPR) subsidy. The following is the data on Islamic mortgage financing at Islamic bank XYZ.

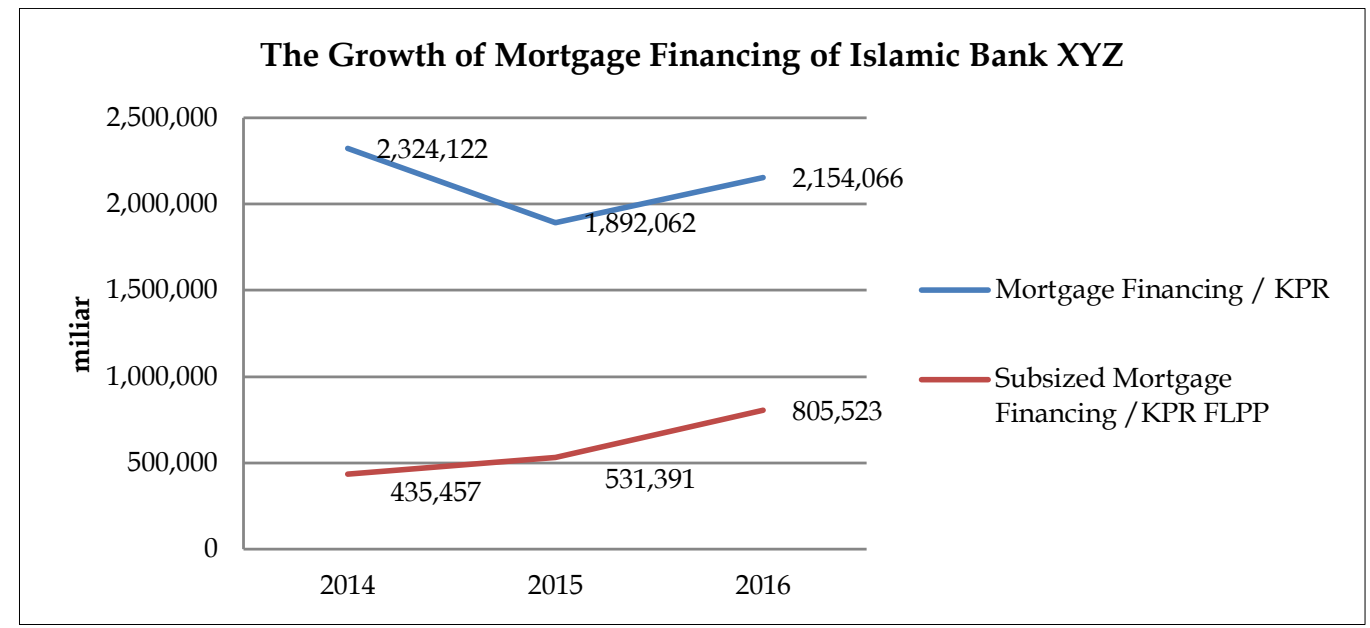

Figure 1. Mortgage Financing in Islamic Bank XYZ 2014 - 2016 Source: Annual Report of Islamic Bank XYZ Year 2016

In the graph above (figure 1) shows the volume of mortgage financing always increases each year, the period 2014 to 2015 a decrease of $18.59 \%$ from the previous year, and in 2016 KPR in Islamic bank XYZ became the largest contributor of total financing channeled Bank Islamic XYZ in the segment consumption of $52.00 \%$ and at the end of 2016 mortgage financing disbursed reached Rp2.15 trillion, an increase of $14.00 \%$ from the year 2015 reached 
Rp1.89 trillion. In 2016, subsidized KPR program is a mainstay feature to increase the growth of mortgage financing in this Islamic bank $\mathrm{XYZ}$, where mortgage financing can be used for home ownership, as well as for renovation or refinancing of assets. Mortgage revenues at Islamic bank XYZ in 2016 reached $\mathrm{Rp} 240$ billion or a portion of $9.10 \%$ of the total revenues of Islamic bank XYZ financing of Rp 2.63 trillion.

Nevertheless, the increase of financing will also be followed by an increased risk of losses to be borne by banks in the form of the inability of customers to return the principal that has been received. Based on the research, $80 \%$ financing risk associated with portfolio assets of islamic banks of the world caused by the failure of debtors to pay financing (Khan in Iqbal, 2006). This is the underlying importance of research on the factors that affect the return of mortgage financing is done, with the hope that it can provide input to the bank in providing financing facilities to prospective customers with the aim to minimize the risk.

\section{Literature Review}

Arifin (2015) explained that financing is the most important activity that is always used in Islamic financial institutions. Financing is a tradition of moslems since the time of the Prophet Muhammad by using the agreement. These activities include the receipt of assets, lending money for business purposes, and conducting money transfer services. Hardjono (2008) explained that KPR or Home Ownership Financing is one type of financing services provided by banks to debtors who want a special loan to meet the needs in the construction of a home or home renovation. KPR itself arises because of the need to have a house that is getting higher and higher without adequate purchasing power balance by the community.

According to Fatmasari (2011), mortgages are generally divided into 2 types, namely: I) Non-Subsidized KPR is a KPR that is intended for the entire community without any government intervention. The mortgage provision is determined by the bank itself so that the determination of the interest rate on 
the conventional bank and margin on the Islamic bank is done in accordance with the policy of the bank concerned. II) Subsidized KPR is a financing that is destined for people with low to middle economic capability. The form of this subsidy has been regulated by the government, so not all communities can apply for this type of financing. In general, the limit set by the government in subsidizing is the applicant's income and the maximum financing provided.

In the Islamic KPR which is transacted is goods (house) with the principle of sale and purchase, not with money as in the conventional mortgages. The Islamic bank buys the house from the developer and the bank sells it to the customer or debtor with the agreed agreement at the beginning of the agreement, and pays it in installments. From the background that has been explained that Islamic bank XYZ in 2016, subsidized KPR program is a mainstay feature to increase the growth of mortgage financing in this Islamic bank XYZ, where mortgage financing can be used for home ownership, as well as for the need for renovation or refinancing of assets.

According to Bank Indonesia Regulation No: 5/7/PBI/2003 regarding the quality of Earning Assets for Islamic Banks in Article 1 paragraph 1 says the financing of Islamic bank in productive activities shall be implemented based on the concept of prudence, based on business feasibility analysis by taking into account at least factor 5C (Character, Capital, Capacity, Condition of Economy and Collateral). And Article 1 paragraph 2 of the Islamic Bank administrators shall control and take anticipatory measures so that the quality of Earning Assets is always in a smooth state, by overseeing the development of the business from time to time and taking action and prevention of possible failure in fund placement. Safitri (2013), Basically, the 5C principle is the basis of credit scoring model as tool, especially to help assessing the character and capacity aspects, both aspects are used as numerical analysis and made into scores that will describe the level of worth whether or not the debtor is given financing.

Some studies have been conducted to study about the Islamic mortgage financing. Safitri (2013) conducted a study on the credit scoring evaluation analysis model of quality of KPR FLPP Financing (Liquidity Facility for 
Housing Financing) Case Study at Islamic Bank X by using logistic regression analysis model to see financing probability at KPR FLPP. There are six most influential variables in this study which consist of education, salary, track record of Bank Indonesia, reference, return ratio, and bank finance. Of these six variables can be used to find out quickly whether a debtor can do housing finance or not. In addition, Haris (2007) argued that the diversity and difference of figh scheme usage in mortgage financing by Islamic bank-sharia bank in Indonesia has negative value and positive value.

Meanwhile, some studies on the repayment rate of Islamic financing have been conducted. Handoyo (2009) concluded that educational level and business experience of customers have positively affected the success of repayment. Nabilah (2015) conducted a study on risk analysis and factors affecting the repayment rate of Islamic financing in agriculture sector with case study of BMT As Salam, Keramat, Demak. The results of this study indicate that the risk of having a high probability and high impact is the lack of customers in the knowledge of the sharia contracts used and the customer being late in returning returns. Likewise, Racmat (2011) stated that factors significantly influencing the return of financing are the period of financing (individual characteristics), and financing ceilings (business characteristics). Hasibuan (2010) said on the results of his research that age is also inversely related to the return of rural business loans related to the agribusiness sector.

In regard to the customer's preference in selecting housing loan products, Krisnawati et al. (2009) concluded that the holding commission has the first priority level for respondents in choosing mortgage products, while the sequential order of other factors consists of the credit approval process, process services, interest rates, credit requirements, marketing information, bank location, credit period, credit costs, down payments and the last priority are gathering events. 


\section{Method}

The research is case study, using descriptive method of analysis with quantitative approach, which means that the research emphasizes its analysis on numerical data, which aims to test the relationship between dependent variable and independent variables to produce conclusion that will clarify the description of the object under study. This study examines what are the factors that significantly affect the return of Islamic financing at Islamic bank XYZ area Jakarta, Bogor, Depok, Tangerang, Bekasi and Cilegon in the period 2014 to 2016.

The sample used in this study are all regular mortgage borrowers in Islamic bank XYZ with branch in Jakarta, Bogor, Depok, Tangerang, Bekasi and Cilegon areas for the period of 2014 - 2016. Respondents used in this study were 422 respondents consisting of 384 debtors with the status of smooth returns (collectibility 1) and 38 debtors with low quality financing returns (collectibility 2-5). The type of data used in this study uses secondary data, where secondary data obtained from the literature study and information related to the research, which is data sourced from data related to regular mortgage borrowers of Islamic bank XYZ area Jakarta, Bogor, Depok, Tangerang, Bekasi, Cilegon and annual data related to Islamic Bank XYZ concerning regular mortgage financing in period range 2014-2016.

Data processing in this research using computer device with software program Microsoft Excel 2010 and SPSS V.20. To know the factors that influence the repayment rate of regular mortgage financing in Islamic bank XYZ used quantitative analysis. Quantitative analysis will be done using Logistic Regression Analysis model. Logistic regression known as LOGIT is part of the regression analysis. So that can be known variable of predictors that have an effect on return of regular mortgage financing at Islamic bank XYZ area Jakarta, Bogor, Depok, Tangerang, Bekasi, and Cilegon. For stages in logistic regression analysis consists of descriptive statistics and hypothesis testing.

In this research the method used is logistic regression analysis method to analyze the factors that affect the return rate of mortgage of regular Islamic 
loan at Bank XYZ Islamich area Jakarta, Bogor, Depok, Tangerang, Bekasi and Cilegon. Rosadi (2011) defines that logistic regression is one statistical model that can be used to analyze the relationship pattern between a set of independent variables with a categorical or qualitative dependent variable. The category of the dependent variable consists of two possible dichotomous values, such as yes or no, success or failure, and more, or more than two (polychotomous) values, such as strongly disagree, agree, disagree, and strongly agree. The purpose of logistic regression analysis is to know how far the model used to predict group categories of individuals (Kuncoro, 2001). The advantages of logistic regression methods are more flexible than other techniques, namely: (I) Logistic regression has no assumption of normality over the independent variables used in the model; (II) The independent variables in the logistic regression can be mixed from the continuous, discrete, and dichotomous variables and; (III) Logistic regression is useful if the response distribution of the variables is expected to be non-linear with one or more independent variables (Kuncoro, 2001).

The logistic model that will be used in this study is the general form of binary logit regression as follows:

$$
Y=\operatorname{Ln}\left[\frac{P_{1}}{1-P_{1}}\right]=b_{0}+b_{i} X_{1}+b_{i} X_{2}+b_{i} X_{3}+\cdots+b_{20} X_{20}
$$

Thus the model equation of this study is as follows, where:

$\mathrm{Y}=$ response variable

$\mathrm{P}=$ Opportunity for $\mathrm{Y}=1$ (Current financing)

1-Pi $=$ Opportunity for $\mathrm{Y}=0$ (low quality financing)

$\beta 0=$ Interspective Logistic Regression

$\beta i=$ Coefficient variable of the estimator $i(i=1-20)$

$X i=$ Estimator variable $i(i=1-20)$, consists of

$\mathrm{X} 1=$ Variable age estimator

$\mathrm{X} 2=$ Variable estimator number of dependents

X3 = Educational level estimator variable

$\mathrm{X} 4=$ Bank account estimator variable 
X5 = Estimator variable the amount of balance held

X6 $=$ Estimator variable track record of XYZ Bank Financing

X7 = Variable track record estimator (BI Checking, collectability)

$\mathrm{X} 8=$ Reversion estimator variable

X9 $=$ Variable estimator of residence status

$\mathrm{X} 10=$ Variable old estimator lives at home at this time

X11 = Estimator variable type of company

X12 $=$ Position position estimator variable

X13 $=$ Variable estimator works long time

X14 = Income level estimator variable

X15 = Estimator variable financing period

X16 = Estimator variable Repayment Capacity

X17 = Appraisal recommendation estimator variable

X18 $=$ Estimator variable building area

X19 = The objective estimator variable of KPR financing

X20 = Financing to Value estimator variable

\section{Result and Discussion}

The data used in this research is the data of financing of KPR Reguler financing at Islamic bank XYZ which is obtained from the Islamic bank XYZ. Data obtained are in the form of age, number of family member, level of education, bank accounts, balance of savings, track record in Islamic bank XYZ, track record in Central Bank of Indonesia, reference, residential status, length of residence, types of firm, position at workplace, length of work, incomes, length of financing, repayment capacity, appraisal recommendation, size of building, purpose of financing, and finance to value. This characteristic describes the parameters of evaluation of regular mortgage financing to customers of Islamic bank XYZ area Jakarta, Bogor, Depok, Tangerang, Bekasi and Cilegon. The characteristics of the respondents of the debtor of Islamic bank XYZ are grouped into five groups of parameters, namely general customer information, residence status, relationship with bank, employment, 
guarantee, and ability to pay customers. Respondents used in this study were 422 respondents consisting of 384 debtors with the status of smooth returns (collectibility 1) and 38 debtors with low quality financing returns (collectibility 2-5).

Factors suspected to affect the return of Islamic mortgage financing at Islamic bank XYZ area Jakarta, Bogor, Depok, Tangerang, Bekasi and Cilegon which consist of age, number of family member, level of education, bank accounts, balance of savings, track record in Islamic bank XYZ, track record in Central Bank of Indonesia, reference, residential status, length of residence, types of firm, position at workplace, length of work, incomes, length of financing, repayment capacity, appraisal recommendation, size of building, purpose of financing, and finance to value. Results of data processing research conducted by using computer programming tool SPSS v.20 using logistic regression analysis.

\section{Feasibility Test of Equations}

A logistic regression equation will be declared feasible and significant if it meets the requirements of equation test that can be done using omnibus test and hosmer-lemeshow test. In appedix 1 , it can be seen that the value of Sig. of the model is 0.000 with the value of $\alpha=0.05$ which means the value of Sig.model is less than alpha $(\alpha=5 \%)$. Hence, it is concluded that the whole independent variables or at least one independent variable influence the financing of Islamic mortgage products.

\section{Determination Coefficient Test}

Next interpretation is the output Model Summary. In appendix 2 The results of the Summary Model are used for the ability of independent variables in explaining the dependent variable, using Cox \& Snell $\mathrm{R}$ Square and Nagelkerke R Square values. These values are also called Pseudo R-Square or in the linear regression (OLS) is better known as R-Square. It can be seen that the value of Nagelkerke R Square is 0.761 and Cox \& Snell R Square 0.571 indicating that the ability of independent variable in explaining the dependent 
variable is 0.761 or $76.1 \%$. In other words, other factors not in the model explain the dependent variable for $23.9 \%$.

\section{Hosmer and Lemeshow Test}

Hosmer and Lemeshow Test Is a model feasibility test. In the Hosmer and Lemeshow Test Sig value. worth 0.677 with the value of $a=5 \%$. As the Pvalue $(0.677)>$ alpha $(0.05)$, It can be concluded that the null hypothesis is accepted, which means the model is suitable. This indicates that the logistic regression equation can be employed to explain the dependent variable and the independent variable.

\section{Table Clarification}

From the data output in the Table Classification Table for logistic regression model (appendix 4), the overall classification accuracy is 91\%, so overall the model used can predict the factors that affect the repayment rate on financing of Islamic KPR products of Islamic bank XYZ area Jakarta, Bogor, Depok, Tangerang, Bekasi, and Cilegon.

\section{Partial Test}

Mathematically, the relationship between independent variables with the dependent variable can be formulated as follows:

$$
\begin{aligned}
\mathrm{Y}= & -0.713-0.150 \text { (Age) - } 0.311 \text { (Number of family member) }-0.137 \text { (Level of } \\
& \text { education) }-0.134 \text { (Bank Account) }-0.059 \text { (Balance of savings) }+0.994 \\
& \text { (Track record in Islamic bank XYZ) }-1.465 \text { (Track record in Central Bank) } \\
& -0.580 \text { (Reference) }-0.058 \text { (Residence Status) }+0.030 \text { (Length of residence) } \\
& +0.026 \text { (Type of firm) }-0.109 \text { (Position at workplace) }-0.053 \text { (Length of } \\
& \text { work) }+0.167 \text { (Income) }-1.188 \text { (Length of financing) }+0.499 \text { (Repayment } \\
& \text { capacity) }-0.041 \text { (Apprasial Recommendation) }+0.169 \text { (Size of building) }+ \\
& 0.247 \text { (Purpose of financing) }+0.372 \text { (Finance to value) }-\beta 0
\end{aligned}
$$

The $\mathrm{t}$ stastistic test basically shows how far the influence of one independent variable individually in explaining the dependent variable. Tests were performed using a 0.1 significance level $(\alpha=10 \%)$. The results indicate that the Track Record in Islamic bank XYZ (X_6), Track Record at Bank Indonesia (X_7), Type of firm (X_11), Length of financing (X_15), and 
Repayment capacity (X_16) has a value smaller than the alpha of 0.10 . This means that the five independent variables affect the dependent variable.

Table 1. Variable in the Equation

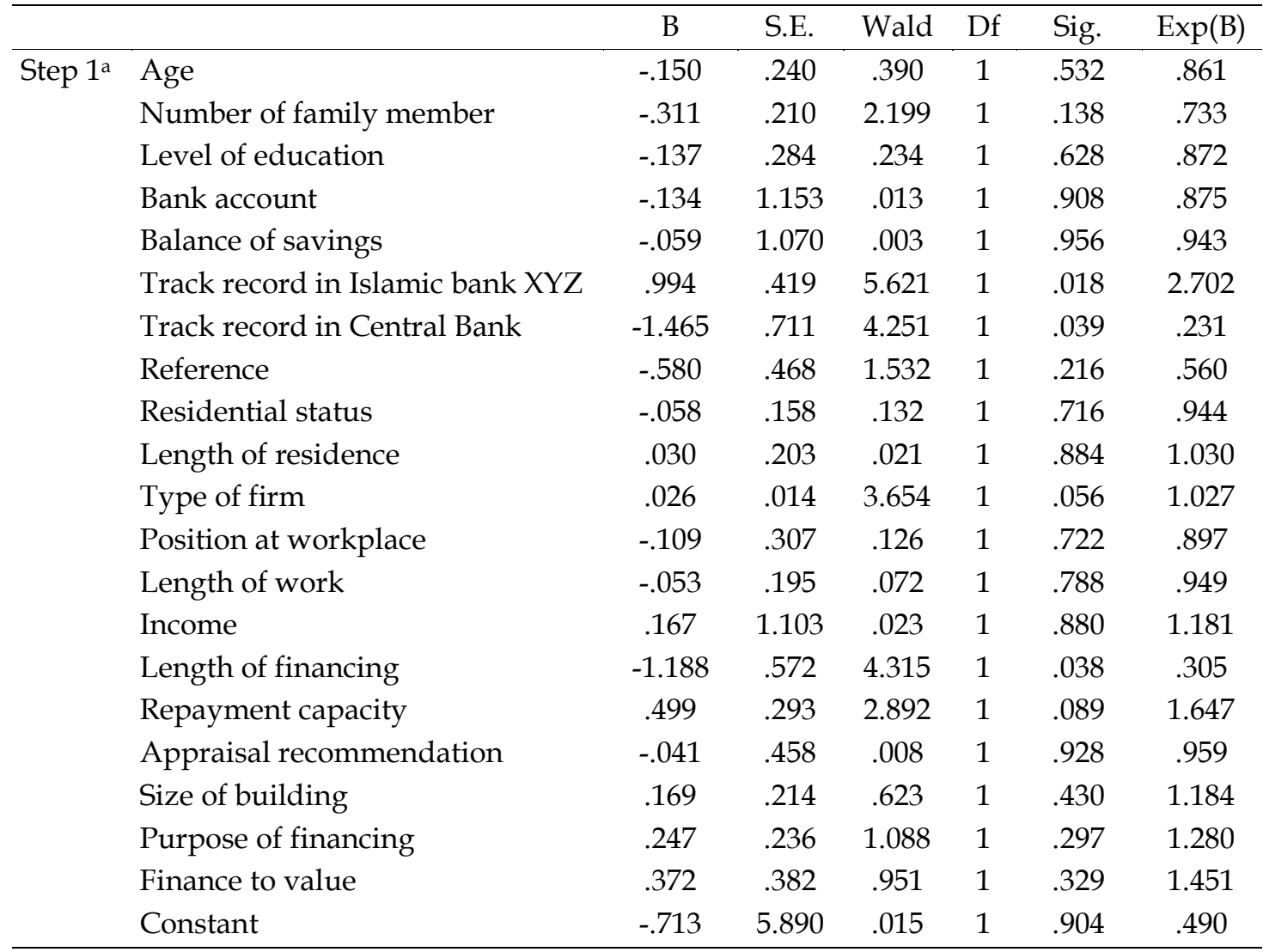

\section{Significant Variables}

Variable of track record at Bank Indonesia also has a role in this financing because the bank can see whether the debtor has a loan in another bank or not. If someone has a loan at another bank, the Islamic bank XYZ can see the collectability of the financing. This is done by the bank to minimize credit risk or financing that will occur, significantly this variable affects the return of Islamic mortgage financing. With a significant value of $0.039<a l p h a$ 0.05 . The coefficient $\left(X \_7\right)$ is -1.465 where the influence coefficient is negative and the Odds ratio value is 0.231 , meaning that the track record at Bank Indonesia is inversely proportional to the return of Islamic mortgage financing.

The Islamic Bank XYZ financing track record variable has a significant effect on the return of Islamic mortgage loans. With a significant value of $0.018>$ 
alpha 0.05 . The coefficient (X_6) is 0.994 where the influence coefficient is positive with an Odds ratio value of 2.702, meaning that the track record of Bank XYZ Sharia financing is directly proportional to the return of Islamic mortgage financing at Islamic Bank XYZ. So, the better the debtor's assessment of Bank XYZ Sharia's financing track record, the higher the chance of returning Islamic mortgage financing to 2.702 times compared to the debtor with the bad track record of Bank XYZ Sharia financing.

Variable types of firm/companies in this study have a significant effect on the return of Islamic mortgage financing. It can be seen from the significant value of 0.36 <alpha 0.05 . With coefficients (X_11) worth 0.026 where the influence coefficient is positive and Odds ratio value is 1.027 , meaning that the type of company is directly proportional to the development of Islamic mortgage financing. This means that the higher the type of company, then the chance of returning Islamic mortgage financing is 1.027 times compared to debtors with lower types of companies. For the financing of regular mortgages (non-subsidized) itself is intended for middle to upper class, unlike the case with FLPP (subsidized) KPR.

For the results of the discussion on the variable period of financing has a significant effect on the return of Islamic mortgage financing. Where significant value is $0.038<$ alpha 0.05 . Coefficient value (X_15) is -1.188 where the influence coefficient is negative and the value of Odds Ratio is 0.305 . Where the financing period is inversely proportional to the return of Islamic mortgage loans. This means that the longer the debtor's financing period, the chance of returning Islamic mortgage financing to be 0.305 kai is lower than the debtor with a shorter financing period.

Repayment Capacity variables significantly influence the return of Islamic mortgage financing with a significant value of $0.089<$ alpha 0.1 . The coefficient (X_16) is 0.499 where the influence coefficient is positive, meaning that the Return Ratio is directly proportional to the return of Islamic mortgage financing. So the better the value of the debtor Return Ratio indicator ratio, the better the chance of returning Islamic mortgage financing. 


\section{Conclusion}

Based on the results of processing using logistic regression, then from several variables that are suspected to have an effect on the return of mortgage product of Islamic bank XYZ mortgage, there are only five significant variables, namely track record variable in Islamic bank $\mathrm{XYZ}$, track record at Bank Indonesia, type of firm, length of financing, repayment capacity. Therefore, to reduce the likelihood of the occurrence of congestion returns mortgage financing, the managerial Bank Islamic XYZ needs to consider the five factors before providing financing facilities to prospective customers of mortgage financing products Islamic bank XYZ.

In the $5 \mathrm{C}$ analysis, the analysis is the basis of the credit scoring model as a tool. Credit scoring model is one of the internal methodologies in Basel II, especially to help assessing the character and capacity aspects. Broadly speaking, these five variables are included in the assessment of character and capacity aspects, the actions that can be performed by Islamic bank XYZ relates to the character in which the debtor who owns or is involved with the loan on the other side other than the Islamic bank XYZ is the need to add research criteria that can be done in the initial analysis. In addition, the bank needs to dig information about the character of the personality (character) of the prospective debtor. Whether the debtor behaves well, always strives to fulfill the promise, and has a good reputation. Such information can be obtained from the community and local officials.

Aspects that can be considered by the bank next is the capacity. Capacity (capability) aims to see the ability of prospective borrowers in paying the financing associated with the ability to manage the business and the ability to seek profit, referred to in terms of terms of financing and ability to pay both related to each other, where the debtor should pay more attention to the assessment of the value of collateral / financing (Bank Finance). The longer the financing period of the debtors, the installments that will be paid by the borrower will be less and the opportunity for return on financing and also the risk of default will be minimized. If it is seen from the results of discussion that 
the financing period is inversely proportional to the return of mortgage financing, here Islamic bank XYZ may conduct Rescheduling, partial or complete reschedule of the debtor by extending the term of credit or installment. This is done if the debtor is not able to fulfill the obligation in the payment of principal installment (based on research report and account officer calculation).

\section{References}

Annual Report. (2016). Accelerated Performance for Sustainable Growth. BRI Shariah, Jakarta.

Arifin, Z. (2015). Musharaka Financing Risk Analysis of Customer Financing Return (Study at PT BPR Islamic Bumi Rinjani Probolinggo). Journal of Business Administration, Universitas Brawijaya Malang, Vol. 28 (2): 2-5.

Fatmasari, N, (2011). Analysis of Conventional Bank Mortgage Financing System and KPRS Financing of Islamic bank (Case Study of Bank BTN with Bank Muamalat). Universitas Negeri Surabaya.

Ghozali, I. (2012). Application of Multivariate Analysis with IBM SPSS 20. Semarang: Publisher Agency.

Handoyo, M. (2009). Factors that Affect the Repayment Rate of Islamic Financing for SMEs Agribusiness on KBMT Wihdatul Ummah Bogor City. Thesis. Bogor: Faculty of Economics and Management, Bogor Agricultural University.

Haris, H. (2007), Housing Financing (An Islamic Banking Financing Innovation). Journal of Islamic Economics, La Riba, Vol. 1 (1).

Hasibuan, R. (2010). Analysis of Factors Affecting the Return on Bad Credit in Rural Business Loan (KUPEDES) Related to Agribusiness Sector (Case of PT Bank Rakyat Indonesia, Tbk Cijeruk Unit, Bogor Regency, West Java). Thesis. Bogor Agricultural University.

Krisnawati, et al. (2009) Perception Analysis Analysis of Housing Loan Products (KPR) XYZ Bank Bogor Branch. Journal of Management \& Agribusiness, Vol 6 (1).

Kuncoro, M. (2001). Quantitative Methods of Theory and Application for Business and Economics. Yogyakarta: AMP YKPN.

Nabilah, S. (2015). Risk Analysis and Factors Affecting the Return Rate of Islamic Financing in the Agricultural Sector (Case Study of BMT As Salam, Kramat Demak). Thesis. Bogor Agricultural University. 
Bank Indonesia Regulation. (2016). Loan to Value Ratios for Property Loans, Financing to Value Ratios for Pretest Financing, and Down Payment for Credit or Motor Vehicle Financing. Bank Indonesia.

Racmat, M. Z. (2011). Analysis Affecting the Return of Financing of Agribusiness at Islamic Commercial Bank (Case on BMI Depok Branch Depok). Thesis. Bogor Agricultural University.

Safitri, D. (2013). Evaluation Analysis of Credit Scoring Model on Financing Quality of KPR FLPP Financing (Liquidity Facility for Housing Financing) (Case Study at Islamic bank X). Thesis: Tazkia University College of Islamic Economics. 
TIFBR | Tazkia Islamic Finance and Business Review

\section{Appendix}

Appendix 1. Omnibus Tests of Model Coefficients

\begin{tabular}{llccc}
\hline & & Chi-square & Df & Sig. \\
\hline Step 1 & Step & 357.161 & 20 & .000 \\
& Block & 357.161 & 20 & .000 \\
& Model & 357.161 & 20 & .000 \\
\hline
\end{tabular}

Appendix 2. Model Summary

\begin{tabular}{cccc}
\hline Step & $\begin{array}{c}-2 \text { Log } \\
\text { likelihood }\end{array}$ & $\begin{array}{c}\text { Cox \& Snell R } \\
\text { Square }\end{array}$ & $\begin{array}{c}\text { Nagelkerke R } \\
\text { Square }\end{array}$ \\
\hline 1 & $227.855^{\text {a }}$ & .571 & .761
\end{tabular}

a. Estimation terminated at iteration number 6 because parameter estimates changed by less than .001 .

Appendix 3. Hosmer and Lemeshow Test

\begin{tabular}{cccc}
\hline Step & Chi-square & Df & Sig. \\
1 & 5.730 & 8 & .677 \\
\hline
\end{tabular}

Appendix 4. Classification Table

\begin{tabular}{|c|c|c|c|c|c|}
\hline & \multirow{3}{*}{\multicolumn{2}{|c|}{ Observed }} & \multicolumn{3}{|c|}{ Predicted } \\
\hline & & & \multicolumn{2}{|c|}{$\mathrm{Y}$} & \multirow{2}{*}{$\begin{array}{c}\text { Percentage } \\
\text { Correct }\end{array}$} \\
\hline & & & Current & Low Quality & \\
\hline \multirow[t]{3}{*}{ Step 1} & \multirow{2}{*}{$\mathrm{Y}$} & Current & 384 & 0 & 100.0 \\
\hline & & Low Quality & 38 & 0 & .0 \\
\hline & \multicolumn{2}{|c|}{ Overall Percentage } & & & 91.0 \\
\hline
\end{tabular}

a. The cut value is, 500 